Sylwester Jędrzejewski SDB

\title{
Pascha w kalendarzach Starego Testamentu
}

Kalendarze zawarte w Starym Testamencie podają dość liczne informacje o różnego rodzaju świętach ${ }^{1}$. Trzy święta ku czci Jahwe ${ }^{2}$, które znane są już w pierwszym okresie istnienia świątyni w Jerozolimie, w pewnym okresie uzyskały status świąt pielgrzymkowych: Pesach na wiosnę, Szawuot po pierwszych zbiorach jęczmienia oraz Sukkot na zakończenie zbiorów pszenicy, oliwek i winorośli. Znaczenie historyczno-religijne tych świąt jest jednak w Starym Testamencie wtórne, rozwinięte na różnych etapach historii zbawienia i formacji tekstów biblijnych. Wynikało ono z procesu budowania tożsamości Izraela, m.in. poprzez zjawisko historyzacji zwyczajów, kultu i norm społecznych. W oparciu o istniejące ryty kultyczne i tradycje przydano im interpretacje odnoszące się do wielkich, fundamentalnych dla etosu Izraela wydarzeń z historii narodu. Święta te były interpretacją i ciągłą relekturą pamięci o wielkich wydarzeniach historycznych oraz okazją do przekazu późniejszym pokoleniom zobowiązań wynikających z wyjścia, przymierza i objęcia ziemi. W centrum tego przekazu tkwi pamięć o wyjściu z Egiptu³.

\section{Teksty paschalne w kalendarzach Starego Testamentu}

Biblijne podstawy dla święta Paschy znajdują się w kalendarzach zawartych w Wj 12, 1-50; Wj 13, 1-10; Wj 23, 10-19; Kpł 23, 5-8; Lb 9, 1-14; 28, 16-25; Pwt 16, 1-84. Aż do Paschy celebrowanej uroczyście przez

${ }^{1}$ Por. sposoby liczenia czasu w: R. Rubinkiewicz, Starożytne kalendarze Bliskiego Wschodu, [w:] Życie religijne w Biblii, red. G. Witaszek, Lublin 1999, s. 257-266; kalendarze liturgiczne omawia S. Bielecki, Starotestamentalne kalendarze liturgiczne, [w:] Życie religijne w Biblii, dz. cyt., s. 267-285; zob. też M. D. Herr, The Calendar, [w:] The Jewish People in the First Century. Historical geography, political history, social, cultural and religious life and institutions, vol. 2, general editors S. Safrai, M. Stern, Philadelphia 1976, s. 834-864.

${ }^{2}$ Zob. szerzej J. Van Goudoever, Biblical Calendars, Leiden, 1961.

${ }^{3}$ Przegląd tradycyjnych opinii o pochodzeniu biblijnej Paschy zob. np. w: T. Prosic, The Development and Symbolism of Passover until 70 CE, London 2004, s. 19-32.

${ }^{4}$ T. K. Hui, The Purpose of Israel's Annual Feasts, „Bibliotheca Sacra” 147 (1990), s. 143 , uważa za kalendarze świąteczne w ścisłym sensie tylko Kpł 23; Lb 28-29 i Pwt 16. 
Jozjasza po znalezieniu Księgi Prawa (622 rok) narracje o obchodzeniu święta, które nosiłoby nazwę Paschy, są nieliczne (Joz 5, 10-11; 2 Krl 23, 21-23). Kolejne pochodzą dopiero od kronikarza, który odnosi się do Paschy sprawowanej za czasów panowania Ezechiasza (726-697; 2 Krn 30, 1-5. 15) i Jozjasza (641-609; 2 Krn 35, 1-19). Podeportacyjną celebrację Paschy ilustruje Ezd 6, 19-22.

\section{OPOWIADANIA PASCHALNE W KALENDARZU WJ 12-13}

Wj 12, 1-13, 16 zawiera wielowarstwowe opowiadanie odnoszące się do Paschy i święta Przaśników według pierwotnego kalendarza, w którym Paschę obchodzi się w miesiącu pierwszym (Wj 12, 2). Wj 12, 1-51 jest narracją zawierająca imperatywne konkluzje ${ }^{5}$. Tekst Wj 13,1-16 wydaje się być retrospektywnym spojrzeniem na $\mathrm{Wj} 15$, który zawiera, jako konkluzje, imperatywne normy teologiczno-prawne.

Celebrację Paschy poprzedzało wybranie zwierzęcia ofiarnego w dziesiątym dniu miesiąca (Wj 12,3). Wyrażenie „dla domu ojców” (lebêt-'ābōt) zdaje się wskazywać na odniesienie do Izraela jako narodu lub na jakąś jego część, np. rodową. Następnie ma miejsce uszczegółowienie, wskazujące na rodzinny krąg uczestników uczty - „dom”. Zaproszenie najbliższego sąsiada ( ̌́ kēnô haqqārōb) w przypadku niewystarczającej liczby uczestników do zjedzenia mięsa baranka sugeruje niewielką grupę rodzinną, jednak z uwagi na strukturę zasiedlenia może oznaczać najbliższych krewnych, a nie jakichkolwiek sąsiadów. „Dom ojców” zdaje się być świadomym podkreśleniem przez hagiografa przynależności rodziny do większej grupy etnicznej. Pascha jawi się zatem jako wydarzenie rodzinne, choć obchodzone w ramach celebracji ogólnoizraelskiej.

Zwierzę ofiarne (śe(h) - Wj 12,5) to samiec jednoroczny wzięty spośród baranków (min-hakkebāŝ́m) lub koźląt (min-hā'izzîm). Termin śeh określa rodzaj zwierzęcia ofiarniczego, jednak bez rozróżnienia gatunkowego. We wczesnej fazie rozwojowej języka hebrajskiego może on oznaczać zarówno baranka, jak i koźlę jako zwierzę ofiarne (kebeś od asyr. kabsëu i ‘ēz). Dalsze ukonkretnienie stanowi bardzo ciekawy termin: zākār. Co oznacza? W Rdz 1, 27 mamy do czynienia z rozróżnieniem: zākār ûneqēbāa $(h)$ - stworzył ich jako „mężczyznę i kobietę” (z wyróżnieniem płci). Tak więc w Wj 12, 5 chodzić będzie zapewne o młodego baranka lub koziołka, zdolnego do bycia zwierzęciem ofiarniczym. Istotny jest nakaz zabicia go „pomiędzy dwoma wieczorami” - bên hā 'arbājim (Wj 12, 6). Mamy tu rzeczownik w liczbie podwójnej - „dwa wieczory”. Być może na późniejsze rozumienie go w liczbie

${ }^{5}$ Wj 12 zaliczany jest do tradycji kapłańskiej podobnie jak Kpł 23 i Lb 9 - por. M. Haran, Temples and Temple-Service in Ancient Israel, Winona Lake 1985, s. 318. 


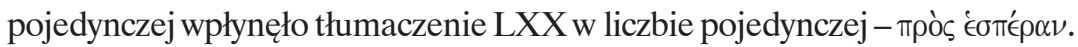
Przyimek mpòs („przed, w bliskości, około”) sugeruje czas po zapadnięciu ciemności lub w bezpośredniej bliskości zmierzchu. W LXX jest zastosowany z accusativem, stąd wyrażenie znaczy: „o zmierzchu” lub „około zmierzchu”.

W Wj 12, 7 znajdujemy nakaz pokropienia krwią framug oraz progów domów, co wyrażono słowem $n t n$. Ten bardzo wieloznaczny termin hebrajski trudno tu jednak tłumaczyć jako czynność pokropienia. Nie ma bowiem mowy o hizopie, jak w Wj 12, 22, ani też o użyciu palca, jak jest wielokrotnie w tekstach kapłańskich, także w odniesieniu do oliwy (Wj 29, 12; Kpł 4, 30. 34; 8, 15; 9, 9;). Dla czynności kropienia w języku hebrajskim używa się określenia $n z h$ w hifil (Kpł 4, 6. 17. 25; 14, 27; 16, 14. 19; Lb 19, 4). LXX

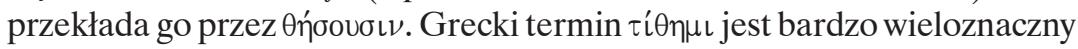
i wyraża jakąś specjalną ekspresję. Może oznaczać, podobnie jak w hebrajskim, m.in. umieszczać, kłaść, nakładać (w znaczeniu celowościowym), a nawet poświęcać. Jest możliwe, że zarówno w tekście hebrajskim, jak i w interpretacji LXX chodzić może raczej o umieszczenie jakiegoś znaku wykonanego krwią na odrzwiach domu, a nie o proste ich pokropienie ${ }^{6}$.

Wj 12, 8: „I zjedzą mięso tej nocy, upieczone w ogniu, i chleb przaśny

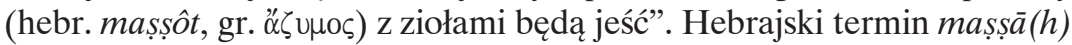
( „chleb bez smaku”) odpowiada w greckim thumaczeniu Septuaginty okre-

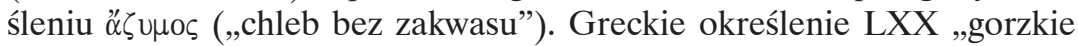

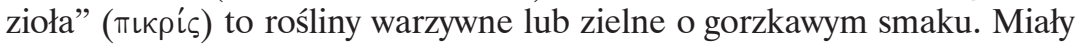
one pomnażać odczucie „chleba bez smaku”. Interpretacja fragmentu dotyczącego mięsa baranka budzi następującą wątpliwość: czy Izraelici zjedzą „upieczone mięso tej nocy”, czy też „mięso upieczone tej nocy” [ballajlä $(h)]$ ? W jednym przypadku oznaczałoby to ucztę paschalną w jakimś krótkim czasie po zabiciu baranka, potrzebnym na upieczenie na ogniu zwierzęcia, jeszcze w nocy. W innym przypadku mogłaby być to uczta urządzana o świcie

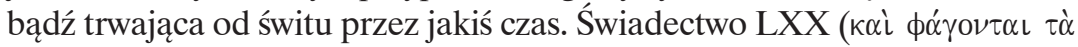

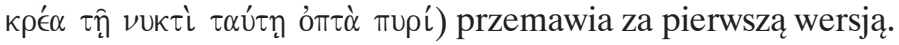

Od Wj 12, 13 rozpoczyna się jakby nowa sekcja, zainicjowana przez ponowne odniesienie do czynności oznaczenia drzwi domów. Wydaje się, że jest to wprowadzenie do późniejszej, uzupełniającej sekcji prawnej, którą znamionować będzie nakaz świętowania Paschy „na wieki”. Nakaz ten zostaje wzmocniony w w. 14. Hebrajski termin zikkārôn nawiązujący do owego dnia oznacza „dzień, który będzie pamiętny”. Pamięć ta wyraża się przede wszystkim w liturgicznej celebracji święta, w której Izrael kontynuuje przeżywanie Paschy jako ciągle aktualizowanego znaku uwolnienia,

${ }^{6}$ Por. L. Kohler, W. Baumgartner, J. J. Stamm, Wielki stownik hebrajsko-polski i aramejsko-polski Starego Testamentu, red. wyd. polskiego P. Dec, t. 1, Warszawa 2008, s. 688-690. 
budującego wspólną tożsamość7. W Wj 12, 15 rozpoczyna się opowiadanie, uprzednio autonomiczne, o celebracji Święta Przaśników. W jego centrum leżało przygotowanie chleba „bez zakwasu”, który był spożywany zrazu tylko w dzień Przaśników. Po rozszerzeniu obchodów spożywano go także w czasie siedmiu dni świątecznych. Następuje więc sekcja, w której widać warstwy relektury i redakcji.

Wj 12, 21 wraca do opowiadania paschalnego. Wersety 22-28 sa w pewien sposób paralelne do ww. 1-14. Wj 12, 22 zawiera poszerzoną w stosunku do Wj 12, 7 informację o pokropieniu krwią przy użyciu hizopu (relektura). Był to ryt oczyszczenia, także z grzechów, stąd można domyślać się takiej aplikacji ${ }^{8}$. Na relekturę wskazuje użycie hebrajskiego słowa $n g$ ‘ w hifil (wehigga'tem), czyli kolejnego - obok ntn i $n z h$ - terminu wyrażającego ideę pokropienia. Tutaj ma ona wyraźny kontekst oddzielenia tego, co sakralne, od reszty. Wj 12, 23 inicjuje kluczowy moment opowiadania. Jahwe ma wkroczyć, by zabić Egipcjan, omijając domostwa oznaczone krwią. Działanie Boga w konkluzji mowy Mojżesza (w. 25) zostaje związane z realizacją obietnicy otrzymania własnej ziemi. Od w. 26 rozpoczyna się hagada paschalna.

Tekst paschalny z Wj, ujęty w struktury chiastyczne, wyglądać może następująco:

Sekcja narracyjna

Wj 12, 1-14: Pascha

[12, 1-6a] Jahwe mówi: Weźcie sobie baranka czternastego dnia tego miesiąca

[12, 6b-7] Pokropcie jego krwią odrzwia waszych domów

[12, 8-10] Ten nocy spożyjcie mięso upieczone w ogniu: nic nie zostawiajcie

$[12,11]$ Spożywajcie w pośpiechu: to jest Pascha dla Jahwe

$[12,12]$ Tej nocy ja zabiję wszystko, co pierworodne w kraju egipskim

$[12,13]$ Krew waszych domów będzie znakiem

$[12,14]$ Ten dzień będzie dla was pamiętny, będzie świętem dla Jahwe

Wj 12, 15-20: Przaśniki

$[12,15]$ Przez siedem dni będziecie jeść chleb przaśny

$[12,16]$ Pierwszego dnia będziecie mieli zwołanie święte

$[12,17]$ Zachowujcie święto Przaśników

$[12,18]$ Pierwszego miesiąca, dnia czternastego będziecie spożywać chleb przaśny

[12, 19-20] Przez siedem dni będziecie jeść chleb przaśny

${ }^{7}$ Por. R. S. Hendel, Israel Among the Nations: Biblical Cultures in the Ancient Near East, [w:] Cultures of the Jews. A new History, ed. by D. Biale, New York 2002, s. 47.

8 „Oczyść mnie z grzechu hizopem, a stanę się czysty” (Ps 51, 9; por. Kpł 14, 6. 14. 49. 51. 52; Lb 19, 18). 


\section{Wj 12, 21-28: Przestrzeganie rytu Paschy}

[12, 21a] Mojżesz zwoła wszystkich starszych Izraela

[12, 21b-23] Jahwe przejdzie jako niszczyciel, nie wejdzie do domów waszych

[12, 24-25] W ziemi, którą da wam Jahwe, przestrzegajcie tego rytu

[12, 26-27] To jest ofiara Paschy dla Jahwe; i ominął wszystkie domy Izraelitów w Egipcie

$[12,28]$ Izraelici uczynili to, co Jahwe powiedział Mojżeszowi i Aaronowi

\section{Wj 12, 29-36: Świadectwo faraona: zostawcie mój naród, idźcie służyć Jahwe}

[12, 29] O północy Jahwe uśmiercił pierworodnego faraona i wszystkich pierworodnych Egiptu

$[12,30]$ Nocą jeszcze wstał faraon i wszyscy Egipcjanie: i podniósł się wielki krzyk

[12, 31-32] Tej nocy faraon powiedział: zostawcie mój naród, służcie Jahwe [...] proście także za mnie

$[12,33]$ Egipcjanie nalegali na lud ponieważ mówili: Wszyscy pomrzemy!

[12, 34-36] Jahwe sprawił, że naród zyskał łaskawość Egipcjan; złupili ich

\section{Wj 12, 37-51: Konkluzja}

[12, 37-38] Wyjście ludu

$[12,39]$ Sporządzenie pokarmu bez zakwasu

$[12,42]$ Noc, w której Jahwe czuwał, będzie dla Izraela nocą czuwania dla Jahwe

$[12,43-50]$ Przebieg rytu Paschy

$[12,51]$ Dzieło Boga: w tym dniu Jahwe sprawił wyjście Izraelitów z Egiptu

Sekcja retrospektywno-prawna

\section{Wj 13, 1-16}

Wprowadzenie: [13, 1-2] Poświęćcie mi wszystko pierworodne [14, 1-2a] Poświęćcie mi wszystko pierworodne, co jest pośród Izraelitów $[13,2 b]$ Człowieka czy zwierzę

[13, 3-10] Spożywać będziecie chleb niekwaszony

$[13,3 a]$ Pamiętajcie: potężną ręką Jahwe wyprowadził was z Egiptu

[13, 4-6] Przez siedem dni będziecie jeść chleb niekwaszony; siódmy dzień będzie świętem ku czci Jahwe

$[13,7]$ Przez siedem dni będziecie jeść chleb niekwaszony

$[13,8]$ To powiedz twojemu synowi. Z powodu tego, co mi uczynił Jahwe

$[13,16]$ Będziesz pamiętał: potężną ręką Jahwe ciebie wyprowadził z Egiptu

$[13,11-16]$ Oddasz dla Jahwe wszystko pierworodne, ponieważ mocną ręką Jahwe was wyprowadził

$[13,11]$ Kiedy Jahwe wprowadzi cię do ziemi, którą da tobie

$[13,12-13]$ Ty oddasz dla Jahwe wszelkie pierworodne

$[13,14 a]$ Jeśli twój syn zapyta cię: Co to znaczy?

$[13,14 b]$ Potężnym ramieniem Jahwe wyprowadził nas z Egiptu

$[13,15 a]$ Jahwe zabił wszystko pierworodne w ziemi Egiptu

$[13,15 b]$ Dla Jahwe będzie każdy pierwszy owoc męski łona matczynego

$[13,16]$ Potężnym ramieniem Jahwe wyprowadził nas z Egiptu

W centrum tekstu paschalnego tkwi pytanie: „Co to znaczy” $(13,14 a)$ ? Odpowiedź znajduje się w 12, 32-32: „Służcie Jahwe”. Sednem narracji Wj 12 jest zobowiązanie do czci Jahwe. Dla nakazu obchodzenia święta Przaśników odpowiednikiem jest wyprowadzenie z Egiptu jako realizacja 
obietnicy nadania ziemi złożonej Abrahamowi, stąd posiadanie ziemi wiąże się z kulturą osiadłą. Dla święta Paschy wyjaśnieniem jest śmierć pierworodnych w Egipcie jako objawienie mocy Boga, który wybiera sobie naród. Śmierć pierworodnych Egiptu przypomina, że wszystko, co pierworodne, należy do Boga i jest poświęcone Bogu. Wybrany Izrael staje się takim właśnie ,pierworodnym” Jahwe. Obrazuje to retrospektywna sekcja prawna Wj 13. Struktura opowiadania pozwala na zestawienie następujących relacji:

1. Jakie znaczenie dla Izraela ma ta noc ze swoimi obrzędami? - Ma przypominać i wzywać do kultu i wierności Jahwe, Bogu Izraela.

2. Jak Izrael ma czcić Jahwe za dar ziemi? - Obchodząc święto Przaśników.

3. Jak Izrael ma czcić Jahwe za wybór na Jego lud? - Obchodząc święto Paschy.

Paschalny tekst z Wj 12 jawi się ostatecznie jako uzasadnienie autorytetu i roli Paschy oraz Przaśników. Czyni się to poprzez umiejscowienie świąt w kontekście fundamentalnych dla etosu Izraela wydarzeń, celowo związanych z wyjściem, wydarzeniami pod Synajem i przymierzem.

\section{KALENDARZ KODEKSU ŚWIĘTOŚCI W KPŁ 23, 5-8}

Cały rozdział 23 Księgi Kapłańskiej jest oparty na starożytnym kalendarzu świątecznym, w wyniku procesu relektury zbudowany z kilku elementów ${ }^{9}$, z których każdy odnosi się do innego święta ${ }^{10}$. Z obchodami Paschy nie jest związane święte zgromadzenie. Oznacza to prawdopodobnie, że możliwe było, w myśl rozumienia tradycji kapłańskiej, obchodzenie Paschy w gronie rodzinnym, bez konieczności udawania się do świątyni w celu rytualnego uboju zwierzęcia ${ }^{11}$. O ile Jozjasz usiłował scentralizować wszelki kult w Jerozolimie, o tyle przeddeportacyjne środowiska kapłańskie powracają, jak się wydaje, do starej praktyki. Z czego wynika ten powrót? Chodzi zapewne o powszechność i skuteczność obchodzenia Paschy oraz podkreślenie dawnej praktyki środowisk kapłańskich, czyli sprawowania kultu w lokalnych sanktu-

9 „El libro del Levítico es claramente fruto de una larga tradición sacerdotal, pero ésta no es homogénea" - J. L. De León Azcárate, Levítico. Comentarios a la Neuva Biblia de Jerusalén, Bilbao 2006, s. 13; zob. też M. Haran, Temples and Temple-Service in Ancient Israel, dz. cyt., s. 317.

${ }^{10}$ Pascha (23, 5); Przaśniki (23, 6-8); święto Pierwocin (23, 10-14); święto Tygodni (23, 15-22); święto Trąbek (23, 24-25); Dzień Pojednania $(23,27-32)$ i święto Szałasów (23, 34-43) - zob. E. Cortese, Su Levitico 25, trent'anni dopo, „Liber Annus” 49 (1999), s. 40; T. K. Hui, The Purpose of Israel's Annual Feasts, dz. cyt., s. 145.

${ }^{11}$ Problem obchodzenia Paschy w gronie rodu, w lokalnych sanktuariach lub świątyni zob. w: A. Paciorek, Najstarsze święta w Izraelu, [w:] Życie religijne w Biblii, dz. cyt., s. 309-313. 
$\operatorname{ariach}^{12}$. Zebranie święte jest przewidziane dla pierwszego i siódmego dnia święta Przaśników. Jakkolwiek oba święta wymienione są oddzielnie, wydają się w tym tekście łączyć jakby w jeden ciąg świętowania. Kanoniczna postać tekstu zawiera zatem w sobie proces łączenia obu świąt. Należy zwrócić uwagę na proporcje w ilości tekstu odnoszącego się do Paschy w stosunku do Przaśników. Zapewne zakłada to powszechną znajomość w środowisku kapłańskim rytu Paschy i stabilność jego celebracji. Jedyny problem mógł tkwić w ujednoliceniu daty jego obchodzenia. W odniesieniu do Paschy nie ma właściwie jakichkolwiek informacji poza datacją.

\section{TEKST PASCHALNY WE FRAGMENTARYCZNYM KALENDARZU LB 9, 1-14}

Tekst ten jest oryginalną legislacją Księgi Liczb - w ramach narracji o posłudze kapłanów - i nie ma paraleli w żadnej innej księdze Starego Testamentu ${ }^{13}$. Składa się z dwóch zasadniczych części: ww. 1-5 i ww. 6-14. Pierwsza sekcja jest, jak się wydaje, pierwotną narracją Paschy, i tylko Paschy, bez święta Przaśników. Druga sekcja jest własnym tworem Lb, ale też charakteryzuje się pewną złożonością. Wersety 6-8 stanowią wprowadzenie do problematycznej kwestii obchodzenia Paschy razem z pobratymcami w sytuacji kontaktu ze zmarłym. Zapewne jest to pytanie rodzące się w sytuacji, w której detale stawały się bardzo ważne. Kluczowe dla interpretacji drugiej sekcji (zwłaszcza wersetów 10-14), wyjaśniającej problem, będzie wyróżnienie poszczególnych warstw tekstu.

[w. 10] «Powiedz synom Izraela, mówiąc:

Sekcja I: [Każdy człowiek] który będzie nieczysty z powodu życia człowieka [tzn. jego śmierci] albo będzie w drodze dalekiej [tzn. w podróży],

[wy] i pokolenia wasze, niech obchodzi Paschę dla Jahwe

12 Wielu egzegetów tradycję kapłańską postrzega jako rytualistyczną i formalną - zob. M. Douglas, Leviticus as Literature, Oxford 1999, s. 89.

${ }^{13}$ Por. T. R. Ashley, The Book of Numbers, Grand Rapids 1993, s. 178. Istnieje jeszcze w Lb tekst paschalny we fragmentarycznym kalendarzu Lb 28, 16-25. Ze źródłowego przekazu kapłańskiego sprzed deportacji zachowano w tym kalendarzu niewiele. Jest to tylko stwierdzenie umiejscawiające Paschę w miesiącu pierwszym, w dniu czternastym. Równie lapidarny jest przekaz odnoszący się do pierwotnej wersji święta Przaśników: datacja i nakaz spożywania chleba przaśnego. Główną treścią jest za to dość szczegółowy opis ofiar, poczynając od pierwszego dnia święta Przaśników do dnia siódmego. Oba dni mają być uroczyście obchodzone przez całą wspólnotę. Konkluzją jest zakaz pracy. Ze szczegółowego opisu ofiarniczego i zakazu pracy wnosić można o kapłańskim charakterze tego tekstu, z pewnością na etapie jego redakcji. Lapidarność nawiązania do Paschy i Przaśników wskazuje nie tylko na ich starożytność, ale też na już utrwaloną i dobrze znaną tradycję ich obchodzenia. Prawdopodobnie na etapie redakcji zaczyna się też kształtować obyczajowość i normatywność pozostałych pięciu dni Przaśników. W praktyce przeddeportacyjnej nie miały one uroczystego charakteru i zapewne były zwyczajnymi dniami pracy. 
[w. 11] w miesiącu drugim czternastego dnia, o zmierzchu będą obchodzić ją; chleb przaśny i gorzkie zioła będą spożywali.

[w. 12] Nie pozostawią nic do rana; a kości nie złamią w nim; zgodnie z każdym przepisem uczynią z nim [tzn. z barankiem].

Sekcja II: [w. 13] A człowiek, który jest czysty i nie jest w podróży,

a zaprzestanie obchodzenia Paschy,

będzie wyłączony z życia ludu swojego;

bo daru ofiarnego nie przyniósł w oznaczonym czasie; grzech swój poniesie człowiek taki [tzn. karę].

Sekcja III: [w. 14] Jeśli zatrzyma się u was jakiś obcy,

będzie obchodził Paschę dla Jahwe,

zgodnie z przepisami Paschy.

te same [przepisy] będą dla was i dla obcego, i dla miejscowych ziemi.

Sekcja I jest bardzo złożona. Dotyczy bardzo szczególnego wypadku, w którym konieczne jest rozstrzygnięcie, czy można razem z pobratymcami obchodzić Paschę, kiedy miało się kontakt ze zwłokami. Odpowiedź jest negatywna. Do tego dochodzi inny przypadek: czy podróż zezwala na obchodzenie Paschy? Odpowiedź także jest negatywna. Dlaczego? Oznaczałoby to, że nastąpiło już przejście z etapu Paschy jako święta obchodzonego w rodzinie do Paschy obchodzonej rodzinnie, ale w świątyni. Stąd rozwiązanie kompromisowe: „w miesiącu drugim (tzn. następnym) czternastego dnia, o zmierzchu będą obchodzić ją”. Jest to coś absolutnie kuriozalnego, nie licząc przesunięcia świąt dokonanych przez Jeroboama I w sanktuariach północnych. Można odnieść wrażenie presji legalizmu. Teraz następuje dziwny wtręt: informacja o spożywaniu chleba przaśnego i ziół, czyli o świętowaniu Przaśników. Sugeruje to redakcyjną interwencję kapłańską z okresu podeportacyjnego. Dalej następuje (w. 12) kontynuacja opowiadania paschalnego i jest to nieomal dokładne powtórzenie starszej narracji z Wj 12, 46.

Sekcja II rozpatruje przypadek, kiedy ktoś, mogąc obchodzić Paschę, nie celebruje jej. Ponadto przypadek, kiedy nie jest w podróży, ale zaniechał z jakichś powodów obchodu Paschy. Zastosowany tu hebrajski czasownik hll ma dość szeroki wachlarz znaczeniowy: od zaprzestania, przerwy, zaniechania, przypadkowego zdarzenia, zaniedbania aż po świadome i celowe odrzucenie. Trudno rozstrzygnąć, o jaki sens tutaj chodzi. Surowość kary (wyłączenie ze wspólnoty) sugeruje świadome zarzucenie celebracji, a jeśli do tego uwzględnić presję jurydyzmu, staje się ona zrozumiała.

Sekcja III jest relekturą Wj 12, 43-49. Być może sytuacja skłoniła do pewnego kompromisu i szanowania faktów już zaistniałych. Ponieważ struktura osiedlenia i zamieszkania była bardzo niejednorodna, obok rodzin izraelskich zamieszkiwali potomkowie różnych nacji kananejskich, ścisły separatyzm mógł być nie do utrzymania. Być może należałoby jeszcze na ten pierwotny kompromis nałożyć także kolejny, który mógł dokonać 
się już w okresie podeportacyjnym. Wtedy środowisko kapłańskie niejako zmuszone zostało do kolejnego ustępstwa. Wobec faktu, że wielu spośród Izraelitów - także kapłanów - powróciło z deportacji z cudzoziemskimi żonami, być może ich dzieci, a nawet oni sami nie byli pojmowani jako pełnoprawni Żydzi. Kompromis był tak daleki, że jednakowe prawo miało obowiązywać Żydów i cudzoziemców, którzy zamieszkali pośród nich. To samo prawo miało obowiązywać też każdego pełnoprawnego obywatela tej ziemi, tutaj urodzonego ('ezrāh ). Gdyby chodziło o dzieci z mieszanych małżeństw po powrocie z deportacji babilońskiej, zabieg ten byłby zrozumiały. Pozwolono w pełny sposób obchodzić Paschę zarówno naturalizowanym cudzoziemcom (prozelitom), jak i uznano za pełnoprawne - a więc mogące obchodzić Paschę - potomstwo deportowanych do Babilonu, pochodzące z małżeństw mieszanych. Do tej kwestii powróci reformatorskie środowisko Ezdrasza-Nehemiasza, przyjmując postawę zdecydowanie radykalną i nacjonalistyczną, akcentującą zdecydowany rozdział wspólnoty podeportacyjnego Izraela i innych nacji ${ }^{14}$.

\section{KALENDARZ ŚWIĄTECZNY W PWT 16, 1-8}

W ramach Kodeksu Przymierza w Pwt zamieszczony jest retrospektywny kalendarz trzech świąt pielgrzymkowych ${ }^{15}$, a w nim tekst 16, 1-8, odnoszący się do Paschy i Przaśników. Trzy święta pielgrzymkowe zostały już zdefiniowane w Wj 23, 14; 34, 18; Kpł 23, 4; Lb 23, 16. Na samym początku perykopy kananejska nazwa Abib wskazuje na pierwotne, źródłowe opowiadanie $^{16}$. Środowisko deuteronomiczne, zgodnie z tendencją reformy Jozjasza, czyni z rodzinnych obchodów Paschy święto sprawowane w „miejscu, które wybierze sobie Jahwe”. Chodzi tutaj zapewne o centralizację kultu w Jerozolimie. Niejako „przy okazji” dokonuje też połączenia Paschy i Przaśników w jeden ciąg świąteczny. Sądzić można, że podkreślanie przez Pwt 16 rolniczego charakteru świąt pielgrzymkowych sugeruje wniosek, iż Izrael przez tę tradycję był postrzegany - lub sam siebie takim widział - jako lud o charakterze rolniczym. Zwrot: „złożysz ofiarę paschalną dla Jahwe, Boga twojego" sugeruje kult świątynny. Do tej pory nie używano takiego określenia, mówiąc tylko o „obchodzeniu Paschy”. Brak jest określenia dnia miesiąca Abib, stąd wnosić można, że tekst ten nie był poddany

${ }^{14}$ Punktem odniesienia dla tej grupy reformatorskiej może być tekst z Pwt 23, 3: „Nie wejdzie syn nieprawego łoża (mamzēr - „bękart”) do zgromadzenia Jahwe, nawet w dziesiątym pokoleniu nie wejdzie do zgromadzenia Jahwe" - por. P. D. Miller, The Religion of Ancient Israel, Louisville 2000, s. 160.

${ }^{15}$ Por. P. C. Craigie, The Book of Deuteronomy, Grand Rapids 1976, s. 242.

${ }^{16}$ Po deportacji używano zazwyczaj nazwy Nisan, jakkolwiek tradycja kapłańska kontynuowała używanie przeddeportacyjnych określeń liczbowych. 
redakcyjnemu wpływowi kapłańskiemu, albowiem tylko teksty kapłańskie i Ez 45, 21 określają dzień, raczej wieczór, obchodów Paschy ${ }^{17}$. Struktura Pwt 16, 1-8 mogłaby wyglądać następująco ${ }^{18}$ :

\section{Wprowadzenie}

Pierwotne opowiadanie: [w. 1] Przestrzegaj miesiąca Abib i obchodź święto Paschy dla Jahwe, Boga twego,

Dodatek deuteronomiczny: bo w miesiącu Abib wywiódł cię Jahwe, Bóg twój, z Egiptu nocą.

\section{Sekcja I (w odniesieniu do Paschy)}

Teza pierwotnego opowiadania: [w. 2] Złożysz ofiarę paschalną dla Jahwe, Boga twego, z owcy i cielca,

Dodatek deuteronomiczny: w miejscu, które wybierze [sobie] Jahwe, aby zamieszkało imię Jego tam.

Pierwotne opowiadanie: [w. 4b] i nie pozostanie z mięsa, które złożysz na ofiarę wieczorem, na drugi dzień [nic] do rana.

Interpretacja sekcji I (deuteronomiczna): [w. 5] Nie złożysz ofiary paschalnej ani w jednym miejscu bramy [tzn. w żadnej miejscowości], którą Jahwe, Bóg twój, daje tobie, [w. 6a] ale w miejscu, które wybierze Jahwe, Bóg twój, żeby zamieszkało imię Jego;

Konkluzja sekcji I tekstu pierwotnego: [w. 6b] tam złożysz ofiarę paschalną wieczorem, jak zajdzie słońce, w oznaczonym czasie,

Dodatek deuteronomiczny: [kiedy] wywiódł cię z Egiptu.

Epifora tezy sekcji I z tekstu pierwotnego: [w. 7] Upieczesz [na ogniu] i zjesz

Dodatek deuteronomiczny: w miejscu, które wybierze Jahwe, Bóg twój, sobie,

Tekst pierwotnego opowiadania: i zawrócisz rano, i pójdziesz do namiotów twoich.

\section{Sekcja II (w odniesieniu do Przaśników) wprowadzona do tekstu paschalnego}

Teza tekstu pierwotnego: [w. 3b] siedem dni będziesz jadł z ofiarami chleb niekwaszony, Interpretacja deuteronomiczna: [w. 3c] chleb ubóstwa [upokorzenia], [w. 3d] bo w drżeniu [w pośpiechu] wyszedłeś z ziemi egipskiej,

Konkluzja deuteronomistyczna: [w. 3e] dlatego będziesz pamiętał dzień wyjścia twego

z ziemi egipskiej przez wszystkie dni życia twego.

Epifora tezy pierwotnej: [w. 4a] Nie będzie widać u ciebie kwasu we wszystkich granicach twojej posiadłości siedem dni.

Dodatki redaktorskie łączące sekcje I i II (Paschę i Przaśniki) są następujące:

- dodatek deuteronomistyczny: [w. 3a] Nie będziesz jadł razem z nią [z ofiarą paschalną] kwasu;

- dodatek kapłański: [w. 8b] nie wykonasz zajęcia [pracy].

${ }^{17}$ Por. R. de Vaux, Instytucje Starego Testamentu, thum. T. Brzegowy, Poznań 2004, s. 501.

${ }^{18}$ Klasyczny trójdzielny podział tej perykopy: wprowadzenie (w. 1); normy ofiary paschalnej (ww. 2-4); unikatowe, obecne tylko tutaj przepisy o miejscu ofiary paschalnej połączone z normą o niekwaszonym chlebie (ww. 4-8) - por. M. Haran, Temples and Temple-Service in Ancient Israel, dz. cyt., s. 335; Haran proponuje tzw. zjawisko injunkcji, tzn. najbardziej pierwotne przekazy paschalne włączone zostały do tekstu Księgi Wyjścia, a te z kolei znalazły swoją syntezę w paschalnym opowiadaniu w Pwt 16 - por. tamże, s. 341. 
Struktura pierwotnego opowiadania paschalnego składałaby się z następujących wersetów: 1. 2. 4b. 5. 6a. 6b. 7, a struktura pierwotnego opowiadania o święcie Przaśników: 3b. 3c. 3e. 4a.

\section{Interpretacja Paschy w świetle kalendarzy biblijnych}

\section{POLE SEMANTYCZNE TERMINU PESAH}

Etymologia hebrajskiego terminu pesah jest niepewna. Jedne opinie widzą tu egipski rdzeń oznaczający „uderzenie”. Jest możliwe, że Hebrajczycy użyli nazwy egipskiej i zastosowali ją na gruncie semickim. Inne opinie pojmują hebrajski czasownik $p s h \mathrm{w}$ znaczeniu „skakać” lub „przeskakiwać”. Istotnie, Księga Wyjścia rozumie ten termin jako „obejście, ominięcie” czy „przeskoczenie” przez Jahwe domów Hebrajczyków w czasie nocy paschalnej ( $\mathrm{Wj} 12,27)$. Jeszcze inna grupa poglądów koncentruje się na znaczeniu ,przejścia”. Takie znaczenie poświadcza jednak w sposób pewny dopiero tradycja chrześcijańska. Niektóre opinie wskazują na związek z semickim, asyryjskim określeniem pasahu („przejednywać”). Miałby to być obrzęd przebłagalny ku czci bogini Isztar. Inne sugestie wskazują na związek biblijnej Paschy z jednym z elementów rytu przedbiblijnego. Mógłby to być rytualny taniec, odzwierciedlający metaforycznie przejście przez morze $\left(m^{e} h \bar{o} l \bar{a}(h)-\mathrm{Wj} 15,20\right)$. Niewątpliwie taniec towarzyszył nieomal zawsze najstarszym semickim rytom religijnym. Element ofiarniczy (z baranka) także przynależy do niemal wszystkich rytów religijnych, zwłaszcza o charakterze inicjującym w semickim kręgu grup pasterskich. Analogicznie jest w tradycji seminomadycznej i nomadycznej z obyczajem zebrania krwi ofiarniczej i kropienia nią namiotów bądź innych miejsc zamieszkania. W tym przypadku także można mówić o inicjacji, ponieważ obyczaj ten praktykowany był np. przy każdorazowym przemieszczeniu się i rozbiciu nowego obozowiska czy zajęciu nowych siedzib.

Hebrajski rdzeń psḥ tłumaczy się najczęściej jako „przejście”. W znaczeniu czasownikowym pāsah oznacza „przejść”, „ominąć”. Jest to jednak już późniejsze, wydedukowane teologicznie znaczenie. Pierwotne znaczenie pāsah to poruszanie się na jednej nodze wraz z towarzyszącymi temu tańcami i skokami ${ }^{19}$. Pascha bowiem u swych początków łączy się z atrybutami typowymi dla każdego z radosnych świąt semickiego kręgu kulturowego: radością, tańcami, muzyką i śpiewami towarzyszącymi rytom ofiarniczym.

${ }^{19}$ Por. F. Zorell, Lexicon hebraicum et aramaicum Veteris Testamenti, Roma 1968, s. 659. 
Radosny charakter tego święta bliski był analogicznym tradycjom kananejskim $^{20}$. W tekstach Starego i Nowego Testamentu ma też znaczenie ofiary ${ }^{21}$.

\section{RELIGIJNE ZNACZENIE PASCHY}

„Pascha” wydaje się być terminem bardzo starożytnym, pochodzącym jeszcze sprzed czasów formowania się Starego Testamentu. Izraelskie święto Paschy posiada wspólne korzenie z religijnym starożytnym pasterskim świętem o zasięgu ogólnosemickim. Warunki życiowe ukształtowały obyczaje, wśród których znajdowało się doroczne wyjście z pustynnych miejsc zimowych na wiosenne i letnie pastwiska. Leżały one na terenach, które dopiero opady deszczu mogły uczynić użytecznymi dla wypasu stad owiec i kóz ${ }^{22}$. Korzenie hebrajskiego terminu pāsaḥ mogą więc wyrażać pierwotną ideę radosnego podskakiwania stada wychodzącego na wiosnę na pastwiska oraz radość pasterzy. Być może na początku termin ten łączył się z powszechnie obchodzonym na Bliskim Wschodzie świętem wiosennym, u początku nowego roku. Wtedy pasterskie grupy wyrażały swoje dziękczynienie za wiosenny przychówek owiec i kóz. Ta tradycja wiosennego wyjścia i dziękczynienia wiązała się z rytualnym pokropieniem krwią namiotów i miała - jak się wydaje - podłoże antydemoniczne ${ }^{23}$.

Pewien problem stanowi wyjaśnienie, czy pāsaḥ w tekstach biblijnych odnosi się do przejścia anioła śmierci i ominięcia oznaczonych krwią domów, czy też do przejścia przez Morze Sitowia. Różnego rodzaju odniesienia do tego drugiego wydarzenia znajdują się w warstwach narracyjnych, jurydycznych, modlitewnych i prorockich Starego Testamentu ${ }^{24}$.

Problemem jest też to, że teksty biblijne raz odnoszą się do samego święta Paschy, innym razem zaś do baranka paschalnego. $Z$ jednej strony psh oznacza szczególnie uroczystą ucztę w trakcie obchodów święta, z drugiej zaś przedmiot tej uczty. Najczęściej teksty biblijne mówią o ofia-

${ }^{20}$ Por. T. Brzegowy, Doroczne święta pielgrzymkowe Izraela, „Ruch Biblijny i Liturgiczny” 36 (1983) nr 2, s. 103-104.

${ }^{21}$ Por. R. Otto, pāsah; pesah, [w:] Theological Dictionary of the Old Testament, ed. by G. J. Botterweck, H. Ringgren, H-J. Fabry, t. 12, Grand Rapids 2003, s. 7-9.

${ }^{22}$ Bardziej zgodne z realiami jest mówienie o kręgu seminomadycznym niż nomadycznym; wypas kóz i owiec nie był atrybutem nomadów.

${ }^{23}$ Por. T. Brzegowy, Doroczne święta pielgrzymkowe Izraela, art. cyt., s. 106-107.

${ }^{24}$ Tradycja prorocka zdaje się np. rozumieć pāsah w nawiązaniu do obu możliwości interpretacyjnych - Iz 31, 5 zestawia np. cztery różne terminy oznaczające działanie Boga w stosunku do Jerozolimy: gānôn wehișsîl pāsōa h h wehimlît („osłoni i ocali, oszczędzi i zachowa"). Tradycje prawne być może nawiązują do zasady lex talionis ( $\mathrm{Wj} 21,23 \mathrm{nn}$ ) - w odniesieniu do Paschy byłaby to konieczna substytucja krwi, należnej Jahwe - zob. S. Haręzga, Rozwój paschalnego prawodawstwa w świetle tradycji biblijnych, „Ruch Biblijny i Liturgiczny” 37 (1984) nr 3, s. 190-200. 
rowaniu Paschy jako o sakralnym akcie ofiarniczym - wezābahtā pesah (Pwt 16, 2. 5) lub o zabiciu Paschy - šahătû happāsaḥ (Wj 12, 21; Ezd 6, 20). Ponadto informują o pieczeniu Paschy - wajebaššlû happesah (2 Krn 35,13 dotyczy mięsa zabitego już baranka) i o spożywaniu Paschy - 'ākelû 'et-happesah (2 Krn 30, 18) $)^{25}$.

Bardzo ciekawe jest zastosowanie rdzenia psh w $1 \mathrm{Krl}$ 18, 21. Imiesłów w liczbie mnogiej pōsehîm oznacza postawę moralną człowieka. Chodzi o niejednoznaczność w opowiedzeniu się za Jahwe i wynikającą z niej chwiejność w podążaniu za Nim. Chodzenie za Jahwe w Starym Testamencie oznacza wierność przymierzu, analogicznie do wyrażenia: „droga Jahwe”. $1 \mathrm{Krl}$ 18, 26 stosuje rdzeń psḥ na oznaczenie kultycznej formy oddawania czci ołtarzowi przez proroków Baala. Prawdopodobnie chodzić tutaj będzie o rytualny taniec i pokłony wobec ołtarza, co miałoby znaleźć przełożenie na postawę moralną.

Jakąkolwiek przyjąć interpretację, święto Paschy wydaje się mieć bardzo starożytne korzenie. Ryt opisany w tekstach biblijnych suponuje jego matrycę seminomadyczną i pasterską. Elementami składowymi byłyby: migracje wiosenne grup pasterskich ku nowych pastwiskom, ubiór podróżny, prosty pokarm, ofiara w intencji płodności stad zwierzą ${ }^{26}$, apotropaiczny bądź inicjacyjny ryt pokropienia krwią. Obyczaj pasterski z czasem uległ transformacji. Naturalne symbole pasterskie przekształcono w symbolikę historyczną, stały się symbolami migracji ku wolności. Na ostatnim etapie rozwoju nadano mu znaczenie religijne. Ta wtórna i teologiczna interpretacja Paschy upamiętnia ominięcie tych domów, których odrzwia były naznaczone krwią baranka w czasie wyjścia z Egiptu. To wydarzenie stało się centralnym punktem, paradygmatem prawodawstwa, liturgii i życia późniejszego Izraela, zarówno w tradycji kapłańskiej, jak i w kręgach reformacyjnych oraz w teologii prorockiej. Krytyka historyczności wyjścia - prowadzona przez niektórych badaczy - jest nie do utrzymania wobec siły tradycji tego paradygmatu ${ }^{27}$.

${ }^{25}$ Zob. S. Potocki, Misterium Paschy Starego Testamentu, „Ruch Biblijny i Liturgiczny” 41 (1988) nr 4, s. 274-275.

${ }^{26}$ Baranek nie był po zabiciu dzielony do pieczenia w kawałkach, ponieważ odzwierciedlał ideał jedności trzody.

${ }^{27}$ G. Davies, Was There an Exodus?, [w:] In Search of Pre-Exilic Israel, red. J. Day, New York 2004, s. 27: "To establish that there was an Exodus it is not necessary to defend the historicity of the whole Exodus story as we have it. Indeed even a fairly limited application of source criticism to Exodus, which would be widely agreed upon even in these confusing times, would distinguish a Priestly account of the Exodus from older source material and so identify elements of the story which are certainly secondary and unhistorical". 


\section{ZNACZENIE PASCHY W BIBLIJNYCH KALENDARZACH}

W deuteronomicznym kalendarzu miesiąc obchodów Paschy i święta Przaśników nosi nazwę Abib (Pwt 16,1). W ten sposób wyraźnie odnosi się do kalendarza księżycowego, podczas gdy w kalendarzu deuteronomistycznym Paschę obchodzi się miesiącu Nisan. W kapłańskim, często numerycznym systemie liczenia miesięcy używane jest określenie: „w miesiącu pierwszym" (baḥōdeš hāri '̌ôn $)^{28}$. Święto Paschy zaczynano obchodzić w noc pierwszej wiosennej pełni księżyca, co praktycznie zbiega się z wiosennym zrównaniem dnia z nocą. Pascha nawiązywałaby do jednego ze starożytnych świąt orientalnych, które kultywowało środowisko pasterskie. Wj 12, 42 podkreśla nie samo święto, ale noc, w czasie której Hebrajczycy doświadczyli zbawczego działania Boga: „Jest to noc czuwania dla Jahwe [na cześć Jahwe] dla tych, których wyprowadził z ziemi Egiptu”.

Według tradycji kapłańskiej Pascha hebrajska korespondowała z dniem kalendarza słonecznego, w którym rozpoczynał się rok liturgiczny: „Pierwszego miesiąca, czternastego dnia miesiąca, o zmierzchu jest Pascha dla Jahwe". Odbywała się wieczorem 14 dnia pierwszego miesiąca, a następny dzień rozpoczynał obchody siedmiu dni święta Przaśników. Pascha we właściwym sensie to świętowanie bên hā 'arbajim - „między dwoma wieczorami” (Wj 12, 6; Kpł 23, 5; Lb 9, 3. 5). Chodzi więc o dwa kolejne wieczory. W ścisłym zaś sensie istotą Paschy był posiłek z zabitego wieczorem baranka.

Deuteronomistyczny kalendarz w Pwt 16, 6 precyzuje początek święta: bā 'âreb k ${ }^{e} b \hat{o}$ ' haššemeš („wieczorem, kiedy zajdzie słońce”). Rytualny nakaz zabicia baranka po zachodzie słońca nie był chyba przestrzegany zbyt rygorystycznie. Zabijano być może ofiary już po południu 14 Nisan, stąd - po powrocie z deportacji - precyzyjna informacja: kiedy zajdzie słońce. Razem z upieczonym mięsem baranka spożywano chleb bez zakwasu i zioła (Pwt 16, 1-8).

W najwcześniejszych kalendarzach mamy do czynienia również z autonomicznym świętem Przaśników. Oczywiste wydaje się rolnicze znaczenie tej uroczystości. Nie należy jednak przeciwstawiać święto Paschy świętu Przaśników. Współczesne badania pokazują bowiem, że już w tekstach prezentujących patriarchów widoczne jest złączenie elementów pasterskich i rolniczych ${ }^{29}$. Zresztą, wśród świąt Izraela znajdują się głównie te, których pierwotne znaczenie związane było z obrzędowością rolniczą. Wszystkie

${ }^{28}$ Zob. Kodeks Kapłański w Lb 28, 16; Kpł 23, 5.

${ }^{29}$ „For Israel before the state it is possible to demonstrate an opposition between the farming and shepherd population in the hill-country on the one hand and the city states of the plains on the other, but non one between farmers and nomads" (R. Albertz, A History of Israelite Religion in the Old Testament Period, t. 1, Louisville 1994, s. 34). 
one zyskały w procesie relektury znaczenie teologiczne, uzasadniane wyjściem z Egiptu: Przaśniki (Wj 23, 15; 34, 18); święto Tygodni (Wj 23, 16; 34, 22); święto Szałasów (Wj 23, 16; Pwt 16, 13). W okresie przed powstaniem monarchii prawdopodobnie wszystkie te święta były po prostu świętami (haggîm) „ku czci Jahwe” (por. Oz 9, 5) ${ }^{30}$.

Święto Przaśników (maș̣̂t), prawdopodobnie kananejskiego pochodzenia, było związane z ofiarowaniem pierwszego plonu ze zbiorów jęczmienia we własnym, lokalnym sanktuarium szczepowym w ramach pielgrzymki. Rytuał polegał na tzw. „potrząsaniu snopem” w drugim dniu Przaśników (Kpł 23, 11). Ta późna, kapłańska tradycja prawdopodobnie jednak odnosi się do bardzo wczesnego obyczaju rolniczego. Polegałby on na robieniu nowego zakwasu ze świeżo zmielonego ziarna i spożywaniu nowego chleba. We wczesnej, rolniczej tradycji starożytnego Wschodu święto to mogłoby obrazować wiosenne odrodzenie się natury. Można więc mówić o rolniczej analogii do święta pasterskiego, jak to było w przypadku skrapiania krwią nowych siedzib w czasie Paschy. Jednak już w czasach biblijnych dokonało się połączenie obu świąt w jednym obchodzie ${ }^{31}$. W każdym razie w diasporze żydowskiej w Egipcie jeszcze w roku 419 - jak się wydaje - nie było stałego terminu Paschy ${ }^{32}$. Być może dla diaspory nie był jeszcze znany albo też nie miał istotnego znaczenia przepis z Tory Ezechiela o świętowaniu Paschy „w miesiącu pierwszym, dnia czternastego tego miesiąca” (Ez 45, 21), w jednym ciągu ze świętem Pierwocin (Ez 45, 20). W rycie świątynnym w Jerozolimie zachowano preferencje dla ofiary z baranka. Pierwociny zbiorów jęczmienia, przynoszone do Świątyni drugiego dnia Przaśników, zyskały w okresie międzytestamentalnym duchowe znaczenie. Nowy Testament nawiązuje do nich, opisując Mesjasza-Chrystusa jako pierwszy owoc odkupienia i zmartwychwstania, „pierwociny” duchowego żniwa ( $\alpha \pi \alpha \rho \chi \eta ́)$ (1 Kor 15, 23). Nowego znaczenia nabrała w Nowym Testamencie także

${ }^{30}$ Por. R. Albertz, A History of Israelite Religion in the Old Testament Period, dz. cyt., s. 89; Ph. J. King, L. E. Stager, Life in Biblical Israel, Minneapolis 1989, s. 353.

${ }^{31}$ Niektórzy egzegeci są zdania, że połączenie nastąpiło już w początkowym okresie monarchii, wraz ze zbudowaniem świątyni w Jerozolimie; bardziej prawdopodobna jest jednak opinia o okresie reformy deuteronomicznej za Jozjasza - por. R. Albertz, A History of Israelite Religion in the Old Testament Period, dz. cyt., s. 35.

${ }^{32}$ Zob. J. Mélèze-Modrzejewski. Żydzi nad Nilem. Od Ramzesa II do Hadriana, Kraków 2000, s. 56-57. 165-166. Problem dotyczy wprowadzenia stałej daty obchodzenia Paschy i Szawuot w żydowskim domu modlitwy, aspirującym do bycia sanktuarium (dosłownie domem z ołtarzem Boga nieba) na Elefantynie. W tej sprawie pisze ktoś (być może Nehemiasz lub Ezdrasz?) z Jerozolimy do Jedaniaha na Elefantynie (tzw. papirus paschalny). Deuteronomistyczne prawo co do obchodów Paschy nie zostało, jak widać, przyjęte powszechnie, potrzebna była interwencja z Jerozolimy. 


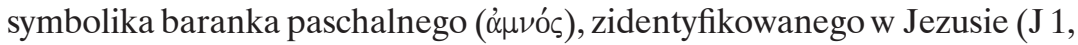

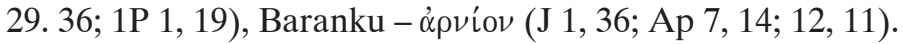

\section{Słowa kluczowe}

Pascha, Przaśniki, kalendarz biblijny, święto pasterskie, kult, Izrael

\section{Summary}

\section{Passover in the calendars of the Old Testament}

The Jewish feast of Pesah was born in the circle of the shepherds' culture, more precisely in the Semitic seminomadic groups. It was being celebrated during the spring, at the beginning of a new year. During the time of Josiah's reforms, it became a pilgrimage feast. Historical experience of the exodus from Egypt and its theological interpretation and several reinterpretations coming afterwards, changed that nomadic and shepherds' feast, connected with agricultural feast of Unleavened Bread, into the most important national feast of Israel. Calendars coming from biblical texts are showing a multistage development of actual feast of Passover.

\section{Keywords}

Passover, Unleavened Bread, biblical calendar, shepherds' feast, worship, Israel 